解 説

\title{
ダイヤモンドの核発生（イオン効果を中心として）
}

\author{
湯 郷 成 美*
}

（受理1994年 4 月 1 日，揭載決定1994年 5 月 7 日）

The Effect of Ion Impinging on the Generation of Diamond Nuclei

\section{Shigemi YUGO}

(University of Electro-Communications, 1-5-1, Chofugaoka, Chofu-shi, Tokyo)

(Received April 1, 1994, Accepted May 7, 1994)

\section{1.はじめに}

熱フィラメント法やマイクロ波プラズマ法によるダイ ヤモンド成長の場合，鏡面基板への核発生は一般的に困 難である．これはプラズマ密度が低い上に，水素濃度が 高く，おまけに基板温度が高いためである。この対策に はスクラッチをつけるなどの基板処理が有効である．特 に超音波振動を利用する微少きずの導入法（超音波処理 法)1)はきわめて有効で各方面で採用されている。この 効用はきずを中心に炭素過飽和が高められ, 迅速に炭素 クラスターが形成できることによると考えられている。

しかし，この方法は核発生密度に上限があり，ランダ ムの核発生となることが難点で, 平滑膜作製やエピタキ シャルへの応用に限界がある。

最近, 我々は電界処理法と呼ぶ, 新しい基板処理法を 提案した 2 ,3). これはマイクロ波プラズマ中に直流バイ アスを重畳して炭素の過飽和度を調節し, さらに炭素イ オンを基板に衝突させて，核の前駆体を基板に植え付け ようとする方法である。例えば $40 \% \mathrm{CH}_{4} / \mathrm{H}_{2}$ のマイク 口波 GVD 中にー $100 \mathrm{~V}$ バイアスで鏡面 $\mathrm{Si}$ 基板を前処理 し, その後に通常のダイヤモンド成長を行うと, 核密度 は $10^{10} / \mathrm{cm}^{2}$ 以上に増加する。

この新しい方法は高密度核発生を可能とするが，これ とは別に, 炭素過飽和度の調節, 非晶質炭素除去, 基板 との反応促進, 水素イオンの働きの助長など核前駆体形 成の基礎的知識を与え, 核発生機構解明の手段になると

\footnotetext{
* 電気通信大学共同研究センター（テ182 東京都調布市調布ケ丘 1-5-1)
}

考えられる.ささらに，本方法はエピタキシャル助長の有 用な道具となることが期待されている.

本報は電界処理法について概説し，これまでのデータ をもとにダイヤモンドの核発生について考えて見ること にした。

\section{2. 実験}

電界処理に使われる装置の概略を Fig. 1 に示す。普 通のマイクロ波 CVD装置であるが，直流バイアスが印 加できるように基板の上部（W 線）と基板支持台（Mo 板）に電極が取り付けてある. 前処理はマイクロ波プラ ズマ中に置かれた基板に対してバイアスを重畳して行 5. 水素に対するメタン濃度を通常より高めに設定し

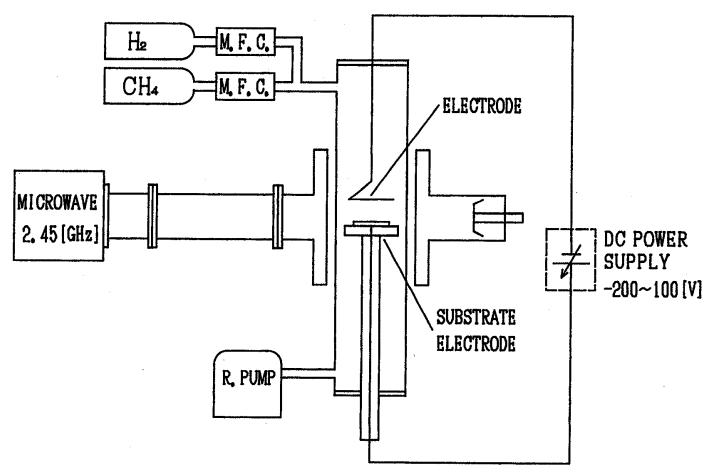

Fig. 1 Schematic diagram of the microwave CVD apparatus. 


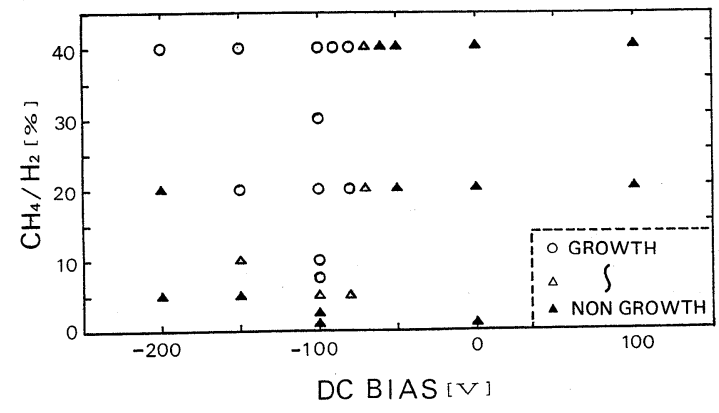

Fig. 2 Diamond generation region as a function of DC bias voltage and methane content.

(2\%以上)，マイクロ波プラズマをたて，その中に置か れた基板に対して直流バイアスをかける，この時の反応 圧力, 基板温度は装置の状況により異なるが，ここでは とりあえず 15 Torr, $900^{\circ} \mathrm{C}$ 設定した.

基板処理後，バイアスを印加しない通常のマイクロ波 CVD でィタン濃度 $0.5 \%$, 圧力 30 Torr に設定してダイ ヤモンド成長を行った。

\section{3. 結 果}

\section{1 バイアス電圧一メタン/水素濃度依存}

バイアス電圧とメタン濃度を变化した時のダイヤモン ド核発生の様子を Fig. 2 亿示す。基板には鏡面 $\mathrm{Si}(100)$ を用いた. 図中の白丸印は核密度が $10^{9} / \mathrm{cm}^{2}$ 以上, 白三 角印は $10^{7} \sim 10^{8} / \mathrm{cm}^{2}$, 黒三角印は $10^{7} / \mathrm{cm}^{2}$ 以下を表わし ている. $5 \%$ 以上のメタン濃度, $-70 \mathrm{~V}$ 以上のバイア スで核密度は急增する。 $-70 \mathrm{~V}$ バイアス付近での核発 生の走査型電子顕微鏡（SEM）写真をFig. 3 亿示した. $-60 \mathrm{~V}$ と $-70 \mathrm{~V}$ の間で核は急増するが, この程度のイ オンェネルギーが核前駆体形成に有効に作用することを 示唆している.

\section{2 電界処理生成物の TEM 観測}

そこでこの前処理の生成物を調べることとした．基板 には電子顕微鏡用 Mo 用メッシュを用いた。試料として $40 \%$ ×タン濃度でバイアス $-50 \mathrm{~V}$ およびー $100 \mathrm{~V} て ゙ 5$ 分間行ったもの，それを水素プラズマで5 分間ェッチン グを行ったもの，さらに，0.5\%で 3 分間ダイヤモンド を成長したものを作製した。これらを透過型電子顕微鏡 (TEM)，制限視野回折（SAED）で観察した。

$-50 \mathrm{~V}$ 処理後の生成物の TEM 像を Fig. 4 亿示す. 主に繊維状生成物が観測されるがこれは比較的結晶性の よい炭素繊維と同定された。これを水素プラズマでェッ チングすると，繊維状物はほとんど除去され，10 $\mathrm{nm}$ 程 度の粒状物が残った。これらはSAEDから Mo 炭化物
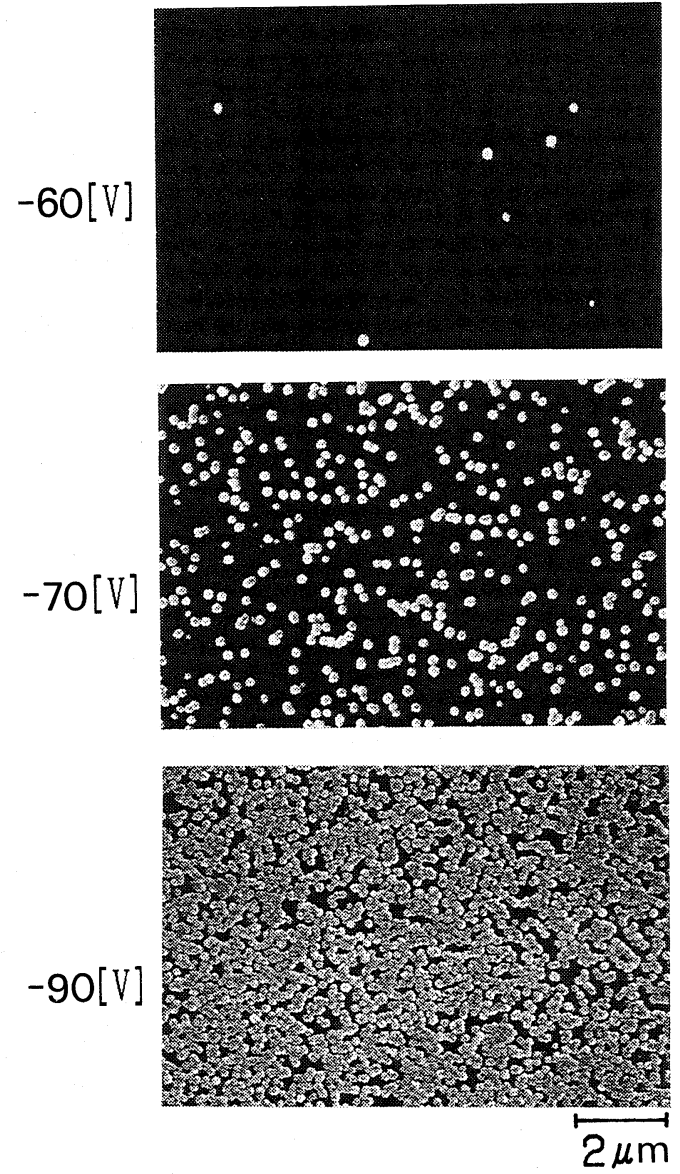

Fig. 3 SEM photographs of grown diamond in $0.5 \%$ $\mathrm{CH}_{4} / \mathrm{H}_{2}$ for 30 minutes on the pretreated substrates in $40 \% \mathrm{CH}_{4} / \mathrm{H}_{2}$ for 2 minutes.

と同定された。このバイアスではダイヤモンドがほとん ど生成しないことから，これら炭素瀻維，炭化物からの 核発生は困難であることが示されている.

$-100 \mathrm{~V}$ 処理後には Fig. 5 の様な密生した生成物が 観測された。これは主にアモルファスカーボンであり, 水素ェッチングによりほほ除去された。しかし，その後 の基板には大別して数 $\mathrm{nm}$ 扰よび $10 \mathrm{~nm}$ 程度の二種類の 粒子が残った. $10 \mathrm{~nm}$ 程度の粒状物はー $50 \mathrm{~V}$ の場合に も見られるもので, $\mathrm{Mo}$ の炭化物 $\left(\mathrm{MoC}, \mathrm{Mo}_{2} \mathrm{C}\right)$ とみ なされるが，一方の数 $\mathrm{nm}$ の微少粒子の同定は難しい. しかし，この時の SAED パターンにダイヤモンド成分 が多く観測されることやダイヤモンド成長後にこの微少 粒子とほぼ同数のダイヤモンド粒が発生することなどか ら，これらはダイヤモンド核ないしは核のプリカーサと 考光ることができる.なお，この数 $\mathrm{nm}$ の粒径は以前に 観測したダイヤモンドの臨界核の大きさにほ浪の致して 

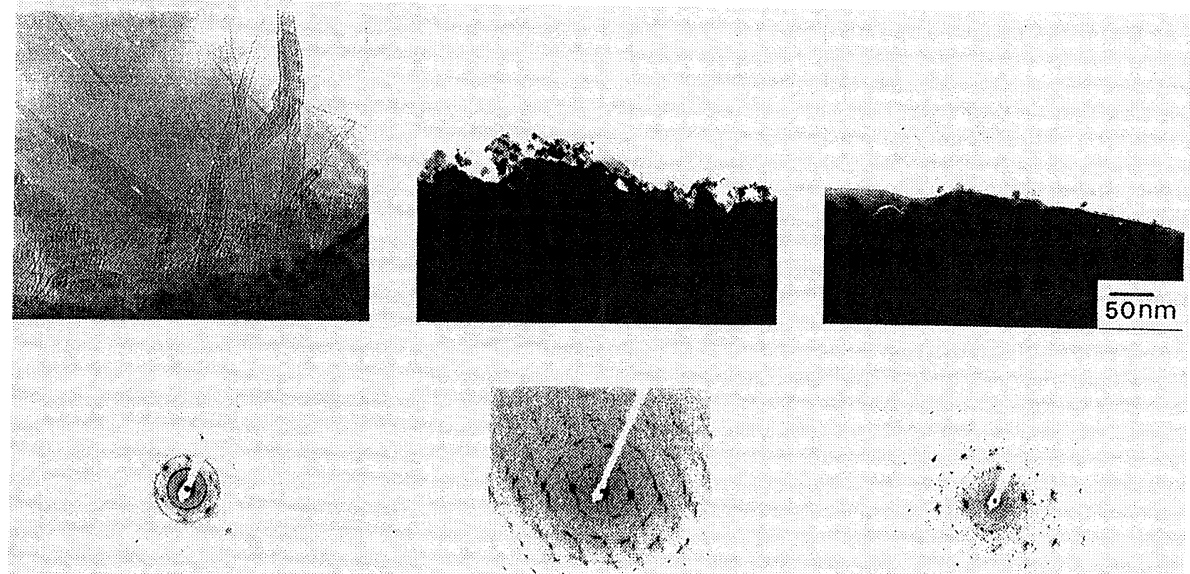

Fig. 4 TEM and SAED photographs of grown materials on the Mo meshes in $40 \% \mathrm{CH}_{4} / \mathrm{H}_{2}$ at $-50 \mathrm{~V}$ for 5 minutes, after $\mathrm{H}_{2}$ plasma etching for 5 minutes and diamond growth in $0.5 \% \mathrm{CH}_{4} / \mathrm{H}_{2}$ for 3 minutes.

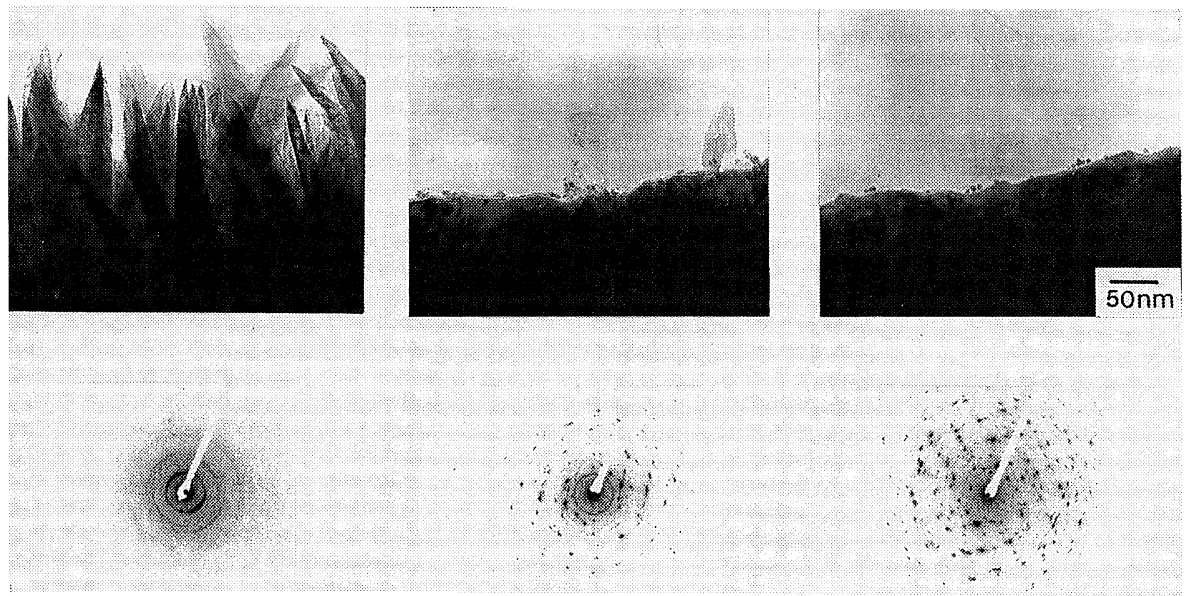

Fig. 5 TEM and SAED photographs of grown materials on the Mo meshes in $40 \% \mathrm{CH}_{4} / \mathrm{H}_{2}$ at $-100 \mathrm{~V}$ for 5 minutes, after $\mathrm{H}_{2}$ plasma etching for 5 minutes and diamond growth in $0.5 \% \mathrm{CH}_{4} / \mathrm{H}_{2}$ for 3 minutes.

いることはこれを裏付けている4).

\section{$3.3 \times$ 3 タアルゴン系での電界処理}

水素の効果を調べるため, 原料を $\mathrm{CH}_{4} / \mathrm{H}_{2}$ から $\mathrm{CH}_{4} /$ Arkかえて処理し, 両者の比較を行った. メタン濃度 が一定にもかかわらず Fig. 6 に示したよらに核密度は $\mathrm{CH}_{4} / \mathrm{H}_{2}$ 系より約 $1 / 20$ に減少した。 $40 \% \mathrm{CH}_{4} / \mathrm{Ar}$ の $-100 \mathrm{~V}$ バイアスでは水素系の場合よりェッチングが押 えられ長い樹木状アモルファスカーボンが生成してい る. これを水素プラズマでェッチングすると, $10 \mathrm{~nm}$ 程 度の炭化物と一部数 $\mathrm{nm}$ の微少粒子が残った。 ここでも 成長後のダイヤモンド粒子数と微少粒子数はほぼ一致し ている.
アルゴンに比べ水素需囲気の方が核発生の促進がみら れるが，核発生にはイオンの物理的効果とともに水素の 化学的働きも重要であることを示している.

\section{4. 考 案}

\section{1 スパッター効果}

基板に到達した炭素原子は表面をマイグレーションし クラスター化して核形成すると考号れる。 しかし水素 プラズマ中の高温基板上では原子の再蒸発がはげしく， クラスター化が困難となっている．これに対処するには 炭素密度を高めることが有効であるが, 今度は $\mathrm{sp}^{2}$ 成分 が多く生成しすぎることが問題となる。 


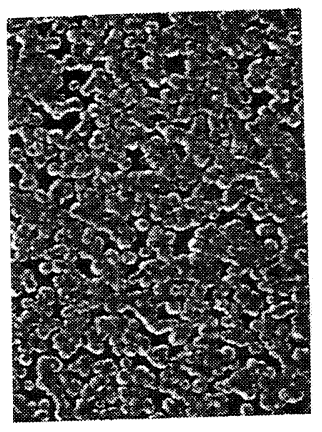

(a)

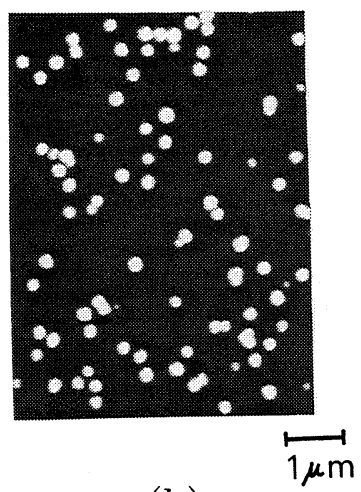

(b)
Fig. 6 SEM photographs of grown diamond on the pretreated substrates at a DC bias of $-100 \mathrm{~V}$ for 5 minutes in $40 \% \mathrm{CH}_{4} / \mathrm{H}_{2}$ (a) and in $40 \% \mathrm{CH}_{4} / \mathrm{Ar}$ (b).

ところで，イオンはシース中で加速され基板に衝突す る.この実効エネルギーは平均自由行程とシース幅で決 定されるが，本実験条件では大略バイアス $100 \mathrm{~V}$ で数 $10 \mathrm{eV}$ 程度である.イオン衝突による基板の変位につい ては $\mathrm{n}_{\mathrm{d}}=\mathrm{E}_{\mathrm{p}} / 2 \mathrm{E}_{\mathrm{d}}$ (Kinchin-Peace の式) の簡単な関係が ある ${ }^{5)}$.ここで, $\mathrm{n}_{\mathrm{d}}$ は変位原子数, $\mathrm{E}_{\mathrm{p}}$ は入射イオンエ ネルギー， $\mathrm{E}_{\mathrm{d}}$ は原子変位のしさい値エネルギーであ る. $\mathrm{E}_{\mathrm{d}} を 14 \mathrm{eV}(\mathrm{Si}), 25 \mathrm{eV}$ (graphite), $80 \mathrm{eV}$ (diamond) とすると, 変位原子数の比はダイヤモンドに対して $\mathrm{Si}$ は 6 倍, 黒鉛は 3 倍程度大きい、イオン衝突による $\mathrm{Si}$ 基板ダメージが大きいことを示している，逆にみると， クラスターに適度なエネルギーイオンが衝突することに より $\mathrm{sp}^{2}$ 成分が分解され， $\mathrm{sp}^{3}$ 成分が選択的に残留する であろらことを予想させる。

\section{2 ミキシング効果}

炭素イオンを $\mathrm{Si}$ 基板に $100 \mathrm{eV}$ で注入すると, 注入層 の深さは約 $0.6 \mathrm{~nm}$ で, その広がりは約 $0.3 \mathrm{~nm}$ である. 先にも示したように Si 原子の変位のしきい值エネルギ 一が小さいため, イオンミキシング層が生じやすい.こ れは炭化物形成を容易にし, 結果的に核と基板の結合が 強化される。これはクラスターの再蒸発を抑え, プリカ 一サ形成を助長するであるう。

ここで本実験条件で基板に照射される炭素濃度を見積 むってみる。メタン濃度を $40 \%$ とし, 前処理時間を 5 分 間，イオン電流を $10 \mathrm{~mA}$ とすると $\mathrm{Si}$ 基板のプロジェク トレンジ内の炭素濃度は $10^{16} / \mathrm{cm}^{2}$ のオーダーである. ダ イヤモンド臨界核の直径が数 $\mathrm{nm}$ であるとすると，その 構成炭素原子数は数百個であるから, 臨界核形成に必要 な炭素原子は十分供給されていると考えられる。

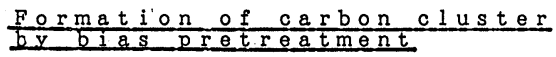

\section{plasma \\ $\mathrm{C}^{+} \mathrm{H}^{+} \quad \mathrm{CH}^{+}$}
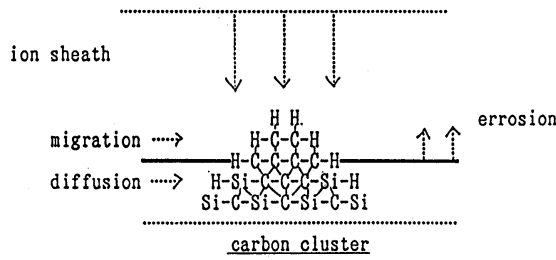

carbon cluster

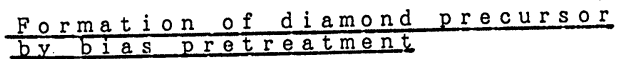

plasma
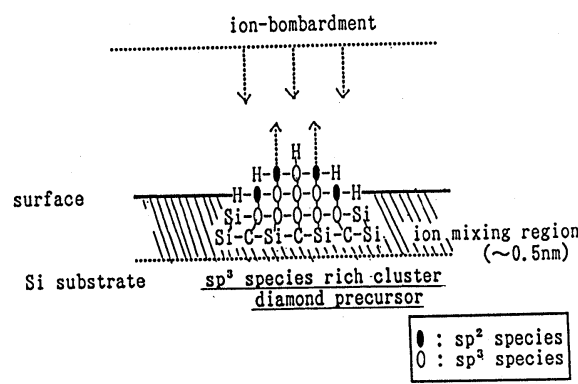

Fig. 7 A model of the generation of diamond nuclei by ion impinging effects. See the text for discussion.

\section{3 水素の効果}

$\mathrm{CH}_{4} / \mathrm{Ar}$ 系でも核発生するが水素系にくらべ核密度は 減少する。核発生にイオンェネルギーのみでなく，水素 の働きも重要であることを示している. 報告によると,



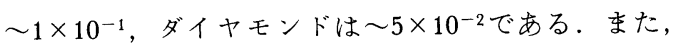
$50 \mathrm{eV}$ と $100 \mathrm{eV}$ の $\mathrm{H}$ イオンでアモルファスカーボンを エッチングすると $\mathrm{CH}_{4} / \mathrm{H}^{+}$の生成量は，それぞれ $5 \times$ $10^{-2}, 2 \times 10^{-2}$ が示されて招り, 水素イオンェネルギー 依存も認められている6). 水素イオンェネルギーを最適 にすると, $\mathrm{sp}^{2}$ 成分が除去されやすく, $\mathrm{sp}^{3}$ 成分が残留し やすいことになる。

一方， $\mathrm{C}_{1}, \mathrm{C}_{2}$ フラグメントからは $\mathrm{sp}^{2}$ が生成しやす く，水素を添加することにより $\mathrm{C}_{1}, \mathrm{C}_{2}$ 生成が抑えられ ることが知られている7)。 その結果, $\mathrm{sp}^{3}$ 成分が形成さ れやすくなると考えられる，また，炭素クラスターがイ

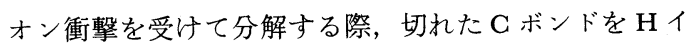
オンが終端して安定化させ, 再び $\mathrm{sp}^{2}$ 構造に戻るのを防 
ぐことも考えられる.

\section{5. まとめ}

過去に非晶質炭素, ダイヤモンド状炭素膜について数 多〈の報告がある ${ }^{8)}$. 注目されることは，これらの生成 イオン衝撃エネルギーが50〜200 eV 程度とされており, ここで述べたダイヤモンド膜が形成されるイオンェネル ギーと共通することである. また水素の有効性も共通し ている。これらは $\mathrm{sp}^{2}$ から $\mathrm{sp}^{3}$ 結合への变換ならびに核 形成の原理が一つであることを示している．核形成プロ セスのシナリオは次のように書くことができる.

1）イオンにより $\mathrm{sp}^{2}$ 成分が効率よく除去できるため 炭素の過飽和度を高めることができ, 再蒸発などに打ち 勝って迅速に炭素クラスターを作ることができる。

2）生成した炭素クラスターはイオン衝撃を繰り返し 受けて結合の弱い $\mathrm{sp}^{2}$ 構造は破壊除去される. 生さ残っ た $\mathrm{sp}^{3}$ 成分が核プリカーサとなる。同時に $\mathrm{sp}^{2}$ から $\mathrm{sp}^{3} へ$ の変換も進行する.

3）イオン衝突は基板とのミキシングを促進して結合 を強化し, 炭素クラスター化を容易にする.

4）水素イオンはプラズマ中の炭素の過飽和度を調整 し非晶質炭素を効率よく除去する。

5）水素は炭素のダングリングボンドをターミネイト して, $\mathrm{sp}^{2}$ 結合を抑え, $\mathrm{sp}^{3}$ 構造を助長させる。

最後に，1）から5）のシナリオと文献9をるとに核発
生機構のモデル図をFig. 7 に示しておく。

\section{[文献]}

1) S. Yugo, T. Kimura and H. Kanai, Proc. 1st Int. Conf. on New Diamond Science and Technology, KTK, Scientific Publishers, Tokyo, 1990, p. 119.

2) S. Yugo, T. Kanai, T. Kimura and T. Muto, Appl. Phys. Lett. 58, (1991) 1038.

3) S. Yugo, T. Kimura and T. Kanai, Diamond and Related Materials, 2, (1992) 328.

4) S. Yugo, A. Izumi, T. Kanai, T. Muto and T. Kimura, Proc. 2nd Int. Conf. on New Diamond Science and Technolgy, Materials Research Society, Pittsburgh, PA, 1991, p. 385.

5) G. H. Kinchin and R. S. Peace, Reports Progress Phys., 18, (1955) 1788.

6) W. L. Hsu, J. Vac. Sci. Technol., A6, (1988) 1803.

7) Y. Muranaka, H. Yamashita, K. Sato and H. Miyadera, J. Appl. Phys., 67, (1990) 6247.

8) 例䒕

S. Aisenberg and R. Chabot, J. Appl. Phys., 42, (1971) 2953.

S. R. Kasi, H. Kang and J. W. Rabalais, J. Vac. Sci. Technol., A6, (1988) 1788.

P. Koidl, C, Wild, D. Dischler, J. Wagner and M. Ramsteiner, Materials Science Forum Vols. 52 and 53, Trans, Tech. Public, Switzerland, 1989, P41.

9）例えば

W. Möller, Appl. Phys. Lett., 59, (1991) 2391.

Y. Lifshitz, S. R. Kasai and J. W. Rabalais, Phys. Rev. Lett., 62, (1989) 1290.

D. Mattox, J. Vac. Sci. Technol., A6, (1988) 1803. 